\title{
PROCESSING CHARACTERISTICS AND ACCEPTABILITY OF JACKFRUIT (Artocarpus heterophyllus Lam.) SEEDS, PHYSICAL AND FUNCTIONAL PROPERTIES OF ITS FLOUR
}

\author{
Sylvia Borgis ${ }^{1}$ \\ ${ }^{1}$ PhD Research Scholar, Department of Food Science and Nutrition, College of Community Science, \\ University of Agricultural Sciences, Dharwad- 580 005, Karnataka, India \\ Pushpa Bharati ${ }^{2}$ \\ ${ }^{2}$ Professor, Department of Food Science and Nutrition, College of Community Science, University of \\ Agricultural Sciences, Dharwad- 580 005, Karnataka, India
}

Article DOI: $\underline{\text { https://doi.org/10.36713/epra5477 }}$

\begin{abstract}
Jackfruit possess 100-400 seeds which are oval, brown and edible after processing. A study was undertaken to investigate 'processing characteristics and acceptability of jackfruit seeds and to evaluate physical and functional properties of its flour'. Ripe jackfruits procured from a single tree at University of Agricultural Sciences, Dharwad campus were cut, and seeds were separated. Seeds were processed by boiling, pressure cooking, pan roasting, microwave roasting, baking. Unprocessed seeds served as control. Effect of processing on characteristics of jackfruit seed was evaluated. Seeds were subjected to sensory evaluation by semi-trained panel members using 9 point hedonic scale. Processed seeds were converted to flour and analyzed for physical and functional properties. Results revealed that weight, volume and edible portion of seeds increased in wet processing but decreased in dry processing. Boiling resulted in better acceptability with acceptability index of 83.15 per cent. Pressure cooked and pan roasted seeds were on par with boiled seeds followed by baked seeds, while microwave roasted seeds had lower acceptability. Flour yield was significantly higher in unprocessed jackfruit seeds (42.17 $\pm 0.06 \%)$. Increase in bulk density was recorded with processing. All processing methods resulted in increased water absorption and oil absorption capacity of jackfruit seed flours. Swelling capacity of jackfruit seed flour increased during moist processing $(6.46 \pm 0.11 \%$ in boiled and $6.24 \pm 0.10 \%$ pressure cooked seeds) and did not decrease significantly in dry processing. The solubility of flours increased during boiling (21.07 $\pm 0.05 \%$ ) and decreased significantly on dry processing (15.63 $\pm 0.20 \%)$. Jackfruit seed flour possess good functional property and hence can be used at domestic, commercial and industrial purpose KEY WORDS: Dry processing, Flour, Jackfruit seed, Moist processing
\end{abstract}




\section{SJIF Impact Factor: 7.001| ISI I.F.Value:1.241| Journal DOI: 10.36713/epra2016 \\ ISSN: 2455-7838(Online) \\ EPRA International Journal of Research and Development (IJRD) \\ Volume: 5 | Issue: 10 | October 2020 \\ - Peer Reviewed Journal}

\section{INTRODUCTION}

Jackfruit (Artocarpus heterophyllus Lam.) is the largest tree-borne fruit belonging to family Moraceae. It is native to India and grown mostly in tropical countries. Pulps are consumed, whereas seeds, rind, core are discarded. Jackfruit seeds are $2-4 \mathrm{~cm}$ long and $1.5-2.5 \mathrm{~cm}$ thick Having oval, ellipsoid or round shape. Depending on size, single fruit may have 100 - 400 seeds. Seeds are used for consumption, culinary purpose and also as source of starch by industries. Only 10 per cent of total seeds obtained are used, while 90 per cent of them are wasted on the whole. Jackfruits being highly seasonal, seeds are available only during March to July. Being a good source of nutrients, possessing therapeutic benefits, consumption of seeds should be encouraged to prevent wastage and enhance nutritional security. Processing improves acceptability, nutritional quality, digestibility, antioxidant activity, storage quality besides reducing antinutrients in food. Though lot of studies regarding jackfruit seed/flour composition and value addition are available, systematic studies revealing the effect of processing the jackfruit seeds are scanty. Hence, the present study was undertaken with the objective to assess the impact of processing on acceptability of jackfruit seeds and to study influence of processing methods on physical and functional properties of its flour.

\section{MATERIALS AND METHODS}

Ripe jackfruits procured from a single tree at University of Agricultural Sciences, Dharwad campus were cut and seeds separated. Colour and shape were recorded by visual observation, size in terms of length, width and thickness was recorded using vernier caliper, weight and volume was noted using electronic balance and water displacement method respectively. Bulk density was calculated. Seeds were processed employing common methods of cooking: a) Boiling $50 \mathrm{~g}$ of seeds was transferred to a vessel containing boiling water and boiled with closed lid at $100^{\circ} \mathrm{C}$ till soft and cooked. b) Pressure cooking - $50 \mathrm{~g}$ of seeds was transferred to a vessel containing $20 \mathrm{ml}$ water. Pressure cooked at $121^{\circ} \mathrm{C}$ till soft and cooked. From a and $b$, excess water was drained and superfluous water was removed by absorbent paper. c) Pan roasting Seeds were roasted at $160^{\circ} \mathrm{C}$ in a pan till sweet aroma developed. d) Microwave roasting - 50g of seeds were microwaved at 480 Power till the seeds turned soft, sweet and developed aroma. e) Baking - Seeds were baked in pre-heated oven at $180^{\circ} \mathrm{C}$ for $15 \mathrm{~min}$ till soft and sweet aroma developed. All processed seeds were cooled. Unprocessed seeds served as control.
Processing characteristics like change in weight and volume of seeds were noted, leached out solids and edible portion were calculated. Processed seeds were subjected to sensory evaluation by semi-trained panel members of Department of Food Science and Nutrition, College of Community Science, UAS, Dharwad using 9 point hedonic scale. Processed seeds were milled to flour and analyzed for physical properties like yield and bulk density and functional properties like water absorption capacity, oil absorption capacity, swelling power and solubility. Mean, standard deviation and analysis of variance (One way ANOVA) was applied to the results. Statistical analysis was conducted using SPSS software (version 16.0).

\section{RESULTS AND DISCUSSION Physical parameters, processing characteristics and acceptability of jackfruit seed}

Jackfruit seeds were brown in colour, oval in shape and comparatively smaller in size with length and width of $3.52 \pm 0.18$ and $1.77 \pm 0.15 \mathrm{~cm}$. The values were in comparison with results reported by Butool and Butool (2013) and Islam et.al (2015). Slightly lower values for length $(2-3 \mathrm{~cm})$ and width $(1-1.5 \mathrm{~cm})$ of seeds were mentioned by Abraham and Jayamuthunagai (2014). These variations can be attributed to the differences in variety, maturity index, location and climatic conditions of cultivation. On an average seeds weighed $5.47 \pm 0.76 \mathrm{~g}$, had volume of $5.25 \pm 0.32 \mathrm{ml}$ and bulk density of $1.06 \pm 0.05 \mathrm{~g} / \mathrm{ml}$.

Weight, volume and edible portion of seeds increased in wet processing and decreased in dry processing (Table 1-See Appendix). Pressure cooking significantly increased weight and volume of the seeds by $5.20 \pm 0.03$ per cent and $10.53 \pm 0.03$ per cent respectively whereas microwave roasting decreased significantly $(13.77 \pm 0.06 \%$ and $12.82 \pm 0.04 \%$ respectively). Direct contact of seeds with water in moist treatment resulted in absorption of water and thus increase in weight and volume. On the contrary, dry processing resulted in loss of moisture and volatile compounds. Further, higher increase in weight and volume lesser leached out solids might have led to significantly higher edible portion in pressure cooked seeds $(97.38 \pm 0.03 \%)$. Open pan roasting at $160^{\circ} \mathrm{C}$ for $15 \mathrm{~min}$ led to a greater escape of moisture and higher decrease in weight $(20.10 \pm 0.04 \%)$ and volume (17.75 $\pm 0.03 \%$ ). The seeds 


\section{SJIF Impact Factor: 7.001| ISI I.F.Value:1.241| Journal DOI: 10.36713/epra2016 ISSN: 2455-7838(Online) EPRA International Journal of Research and Development (IJRD)

which are enclosed in fleshy endosperm cells have a thick cell wall with stored polysaccharides which are heat liable, the loss of these during heating results in separation of brown spermoderm from seeds thus reducing the amount of edible portion.

Table 2(See Appendix) indicates acceptability of processed jackfruit seeds. The processed seeds did not differ significantly with respect to appearance. However, boiled seeds had significantly higher scores for all sensory parameters like color (7.29), flavor (7.48), taste (7.48), texture (7.57), overall acceptability (7.71) with acceptability index of 83.15 . This may be due to softening of texture and increased sugar content during boiling. Acceptability index of pressure cooked seeds (78.30) and pan roasted seeds (76.91) were on par with boiled seeds followed by baked seeds (75.44). Microwave roasted seeds scored significantly lower scores for all sensory parameters like color (6.48), flavor (6.10), taste (5.90), texture (5.57), overall acceptability (6.60) and had lower acceptability with acceptability index of 68.17 , may be due to hardening of texture and ununiform cooking due to rapid processing. However, all processed seeds were within acceptable range of sensory evaluation that is between liked very much to liked moderately. All the sensory parameters were significantly and positively correlated to reducing, non reducing and total sugars and negatively correlated to starch and dietary fiber (Table 3-See Appendix).

\section{Physical and functional properties of processed jackfruit seed flour}

Flour yield was significantly higher in unprocessed jackfruit seeds $(42.17 \pm 0.06 \%)$ as indicated in Fig 1(See Appendix). Among processing methods, significantly lower flour yield observed in moist processed seeds (boiling - $31.46 \pm 0.05 \%$, pressure cooking $-34.70 \pm 0.07 \%$ ) may be due to leached out solids along with other water soluble components, whereas microwave roasted jackfruit seeds yielded significantly higher amount of flour among processing methods $(39.68 \pm 0.05 \%)$. Flour yield depends on type of raw material, initial moisture, composition, variety, size, pre-treatments, processing technique and equipments used. Removal of brown spermoderm during processing may be the reason for lower flour yield in processed seeds.

Increase in bulk density was recorded with processing (Fig 2-See Appendix), which may be due to heat processing (Ejiofor et al., 2014 in jackfruit seed flour and Akubor and Obiegbuna, 2014 in African breadfruit kernel flour) and higher protein content. The results were in comparison with the values reported by
Chowdhury et al. (2012); Abraham and Jayamuthunagai (2014) who reported bulk density values of $0.61 \mathrm{~g} / \mathrm{ml}$ to $0.81 \mathrm{~g} / \mathrm{ml}$ in jackfruit seed flour. The bulk density is used to determine handling requirement.

Effect of processing on functional properties of jack seed flour is presented in Table 4(See Appendix). All processing methods resulted in increased water absorption and oil absorption capacity of jackfruit seed flours. Water absorption capacity was significantly higher in wet processed jackfruit seed flour compared to dry processing, pressure cooking having significantly higher value $(282.71 \pm 0.02 \%)$ compared to unprocessed seed flour (182.36 $\pm 0.03 \%)$. The results were in comparison with that reported by Ejiofor et al. (2014) in processed jackfruit seed flour and Akubor and Obiegbuna (2014) in African breadfruit kernel flour. Water absorption capacity may differ due to molecular structure of flours, protein concentration, interaction with water, conformational characteristics, hydrophilic groups, particle size, degree of milling, presence of husk, damaged starch, protein content and carbohydrates (Kaushal et al., 2012). In the present study, oil absorption capacity of unprocessed jackfruit seeds flour was $89.93 \pm 0.20$ per cent which increased on processing. Dry processed seeds $(115.80 \pm$ $0.92 \%$ to $164.76 \pm 1.17 \%$ ) had significantly higher oil absorption capacity than wet processed seeds $(101.05 \pm$ $0.08 \%$ to $101.26 \pm 0.72 \%$ ). The results were in comparison Abraham and Jayamuthunagai (2014) and Akubor and Obiegbuna (2014) and Ejiofor et al. (2014). Increased oil absorption capacity of processed flours may be attributed to denaturation and dissociation of constituent proteins that may occur on heating which unmasks the non-polar residues from the interior of the protein molecule. The swelling capacity of jackfruit seed flour increased during moist processing $(6.46 \pm 0.11 \%$ in boiled and $6.24 \pm 0.10 \%$ pressure cooked seeds) and did not decrease significantly in dry processing (Table 4-See Appendix). The solubility of flours increased during boiling (21.07 $\pm 0.05 \%)$ and decreased significantly on dry processing $(15.63 \pm 0.20 \%$ to $17.49 \pm 0.41 \%)$. Similar changes were observed by Ejiofor et al. (2014).

Table 5(See Appendix) indicates particle size distribution of processed jackfruit seed flour. Irrespective of processing, higher proportion of jackfruit seed flour was passed through 85 mesh BSS standards sieve having particle size $180 \mu \mathrm{m}$. It ranged from $46.08 \pm 1.50$ per cent in unprocessed seed flour to $31.96 \pm 1.92$ per cent in pressure cooked seed flour. Higher proportion of pressure cooked seed flour was 


\section{EPRA International Journal of Research and Development (IJRD) \\ Volume: 5 | Issue: 10 | October 2020 \\ - Peer Reviewed Journal}

finer with particle size of $200 \mu \mathrm{m}(33.98 \pm 0.89 \%)$ Very less quantity of unprocessed and processed seed flour could be passed through 300 mesh BSS standards sieve having particle size $53 \mu \mathrm{m}(0.47 \pm 0.38 \%)$. On an average higher proportion of jackfruit seed flour was coarser, may be due to usage of domestic mixer for converting dry seed chips to flour. Mechanical milling if employed might result in finer flour.

\section{CONCLUSION}

Boiled jackfruit seeds are highly acceptable followed by pressure cooked and pan roasted. Flour yield is maximum from unprocessed seeds. Unprocessed and processed jackfruit seed flour poses good functional property and hence can be used for value addition at domestic, commercial and industrial level for the replacement of cereal flours in traditional and conventional products or formation of novel products.

\section{APPENDIX}

Table 1 Processing characteristics of jackfruit seeds

\begin{tabular}{|c|c|c|c|c|}
\hline \multirow{2}{*}{ Treatment } & \multicolumn{4}{|c|}{ Processing characteristics (\%) } \\
\cline { 2 - 5 } & Change in weight & Change in volume & Leached out solids & Edibleportion \\
\hline Boiling & $5.20 \pm 0.03^{\mathrm{b}}$ & $10.53 \pm 0.03^{\mathrm{b}}$ & $3.12 \pm 0.04^{\mathrm{a}}$ & $94.45^{\mathrm{a}} \pm 0.05^{\mathrm{b}}$ \\
\hline $\begin{array}{c}\text { Pressure } \\
\text { cooking }\end{array}$ & $8.85 \pm 0.05^{\mathrm{a}}$ & $14.29 \pm 0.03^{\mathrm{a}}$ & $1.44 \pm 0.05^{\mathrm{b}}$ & $97.38 \pm 0.03^{\mathrm{a}}$ \\
\hline Pan roasting & $-20.10 \pm 0.04^{\mathrm{e}}$ & $-17.75 \pm 0.03^{\mathrm{e}}$ & - & $76.32 \pm 0.04^{\mathrm{e}}$ \\
\hline $\begin{array}{c}\text { Microwave } \\
\text { roasting }\end{array}$ & $-13.77 \pm 0.06^{\mathrm{c}}$ & $-12.82 \pm 0.04^{\mathrm{c}}$ & - & $80.49 \pm 0.03^{\mathrm{c}}$ \\
\hline Baking & $-18.82 \pm 0.03^{\mathrm{d}}$ & $-14.22 \pm 0.03^{\mathrm{d}}$ & - & $76.92 \pm 0.03^{\mathrm{d}}$ \\
\hline F value & 298162 & 661260 & 6996 & 201736 \\
\hline S. Em. \pm & 0.16 & 0.12 & 0.10 & 0.14 \\
\hline C. D. at 1 \% & $0.36^{* *}$ & $0.26^{* *}$ & $0.23^{* *}$ & $0.32^{* *}$ \\
\hline
\end{tabular}

**Significant at $1 \%$ level 
SJIF Impact Factor: 7.001| ISI I.F.Value:1.241| Journal DOI: 10.36713/epra2016 ISSN: 2455-7838(Online)

EPRA International Journal of Research and Development (IJRD)

Volume: 5 | Issue: 10 | October 2020 - Peer Reviewed Journal

Table 2 Effect of processing on acceptability of jackfruit seeds

\begin{tabular}{|c|c|c|c|c|c|c|c|}
\hline Treatment & Appearance & Color & Flavor & Taste & Texture & $\begin{array}{c}\text { Overall } \\
\text { acceptability }\end{array}$ & $\begin{array}{l}\text { Acceptability } \\
\text { index }\end{array}$ \\
\hline Boiling & $7.38 \pm 0.80$ & $7.29 \pm 0.90^{\mathrm{a}}$ & $7.48 \pm 0.87^{a}$ & $7.48 \pm 0.93^{a}$ & $7.57 \pm 1.16^{\mathrm{a}}$ & $7.71 \pm 0.85^{\mathrm{a}}$ & $83.15^{\mathrm{a}}$ \\
\hline Pressure cooking & $6.86 \pm 1.24$ & $6.90 \pm 0.83^{\mathrm{ab}}$ & $7.00 \pm 1.00 \mathrm{a}$ & $6.86 \pm 1.06^{\mathrm{a}}$ & $7.24 \pm 1.26^{\mathrm{ab}}$ & $7.33 \pm 0.73^{\mathrm{ab}}$ & $78.30^{a b}$ \\
\hline Pan roasting & $6.86 \pm 1.39$ & $7.00 \pm 1.18^{a b}$ & $6.86 \pm 1.28^{a}$ & $7.10 \pm 1.34^{\mathrm{a}}$ & $6.67 \pm 1.24^{\mathrm{b}}$ & $7.05 \pm 1.12^{b}$ & $76.91^{\mathrm{ab}}$ \\
\hline Microwave roasting & $6.76 \pm 1.14$ & $6.48 \pm 1.29^{b}$ & $6.10 \pm 1.30^{\mathrm{b}}$ & $5.90 \pm 1.55^{b}$ & $5.57 \pm 1.12^{\mathrm{c}}$ & $6.00 \pm 1.22^{c}$ & $68.17^{\mathrm{c}}$ \\
\hline Baking & $7.10 \pm 1.14$ & $6.86 \pm 1.39 \mathrm{ab}$ & $6.76 \pm 0.94^{\mathrm{ab}}$ & $6.76 \pm 1.58^{a}$ & $6.57 \pm 1.29^{b}$ & $6.71 \pm 1.10^{\mathrm{b}}$ & $75.44^{\mathrm{b}}$ \\
\hline F value & 0.99 & 1.38 & 4.36 & 4.09 & 8.30 & 8.56 & 5.184 \\
\hline S. Em. \pm & 0.50 & 0.50 & 0.48 & 0.57 & 0.53 & 0.45 & 4.76 \\
\hline C. D. at $5 \%$ & NS & $0.70 *$ & $0.67^{*}$ & $0.81^{*}$ & $0.74^{*}$ & $0.62^{*}$ & $6.68^{*}$ \\
\hline
\end{tabular}

*Significant at $5 \%$ level

NS - Non Significant 
SJIF Impact Factor: 7.001| ISI I.F.Value:1.241| Journal DOI: 10.36713/epra2016

ISSN: 2455-7838(Online)

EPRA International Journal of Research and Development (IJRD)

Volume: 5 | Issue: 10 | October 2020 - Peer Reviewed Journal

Table 3 Correlation between sensory parameters and chemical composition of jackfruit seeds

\begin{tabular}{|c|c|c|c|c|c|c|c|}
\hline \multirow[b]{2}{*}{ Chemical composition } & \multicolumn{7}{|c|}{ Sensory parameters } \\
\hline & Appearance & Color & Flavor & Taste & Texture & $\begin{array}{c}\text { Overall } \\
\text { acceptability }\end{array}$ & $\begin{array}{l}\text { Acceptability } \\
\text { index }\end{array}$ \\
\hline Reducing sugars & $0.709 * *$ & $0.909^{* *}$ & $0.946^{* *}$ & $0.942^{* *}$ & $0.925^{* *}$ & $0.914^{* *}$ & $0.940^{* *}$ \\
\hline Non reducing sugars & 0.410 & $0.537^{*}$ & $0.680^{* *}$ & 0.489 & $0.772^{* *}$ & $0.729^{* *}$ & $0.688^{* *}$ \\
\hline Total sugars & $0.565^{*}$ & $0.733^{* *}$ & $0.857^{* *}$ & $0.707^{* *}$ & $0.921^{* *}$ & $0.884^{* *}$ & $0.861^{* *}$ \\
\hline Starch & $-0.651^{* *}$ & -0.488 & $-0.560^{*}$ & -0.372 & $-0.539^{*}$ & -0.512 & $-0.553^{*}$ \\
\hline Insoluble dietary fibre & -0.417 & $-0.592^{*}$ & $-0.727^{* *}$ & $-0.561^{*}$ & $-0.800^{* *}$ & $-0.780^{* *}$ & $-0.732^{* *}$ \\
\hline Soluble dietary fibre & 0.219 & 0.228 & 0.115 & 0.259 & 0.061 & 0.068 & 0.123 \\
\hline Total dietary fibre & -0.358 & $-0.520^{*}$ & $-0.661^{* *}$ & -0.486 & $-0.737^{* *}$ & $-0.717^{* *}$ & $-0.665^{* *}$ \\
\hline
\end{tabular}

*Correlation is significant at 0.05 level

**Correlation is significant at 0.01 level 


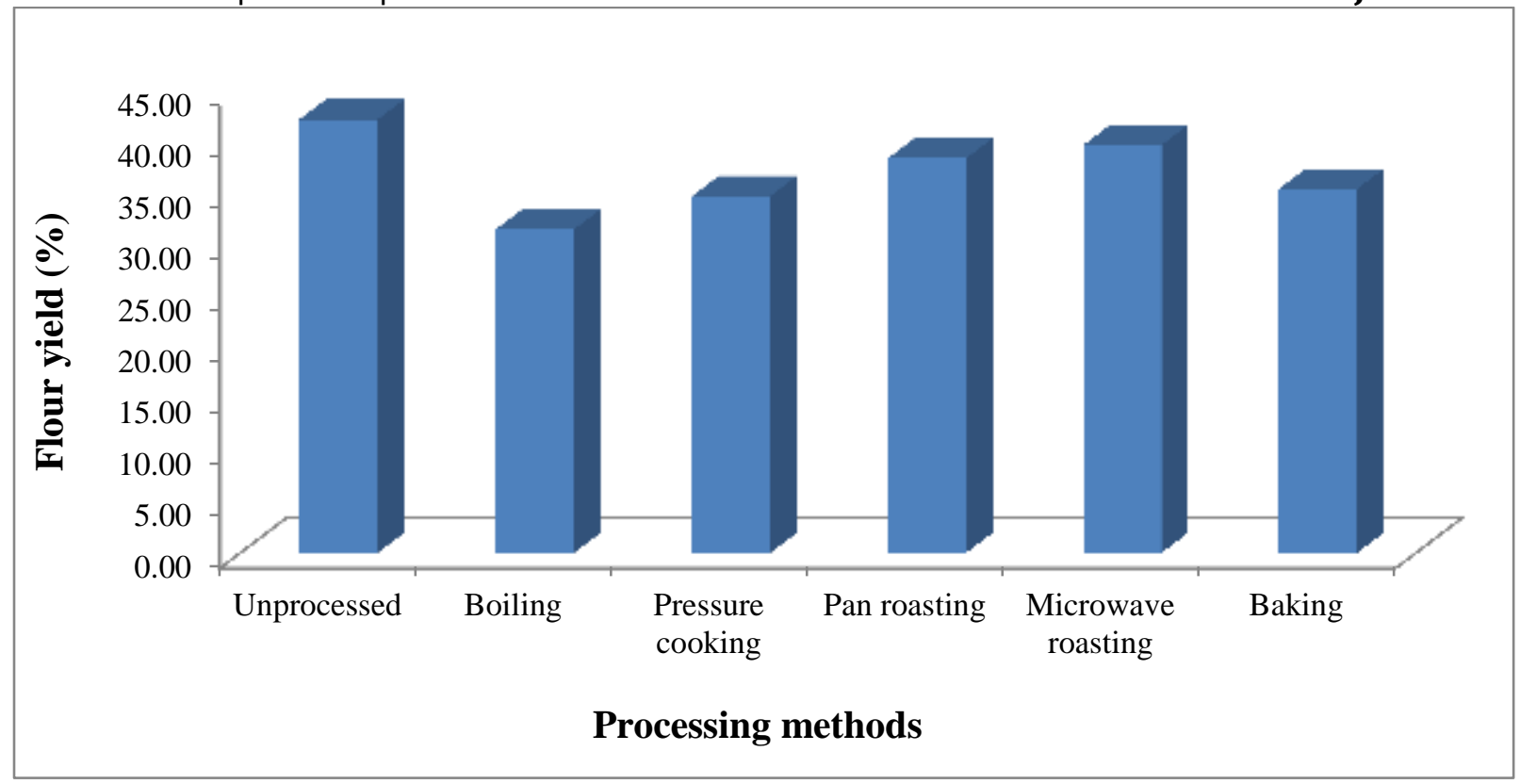

Fig 1 Flour yield (\%) of processed jackfruit seeds

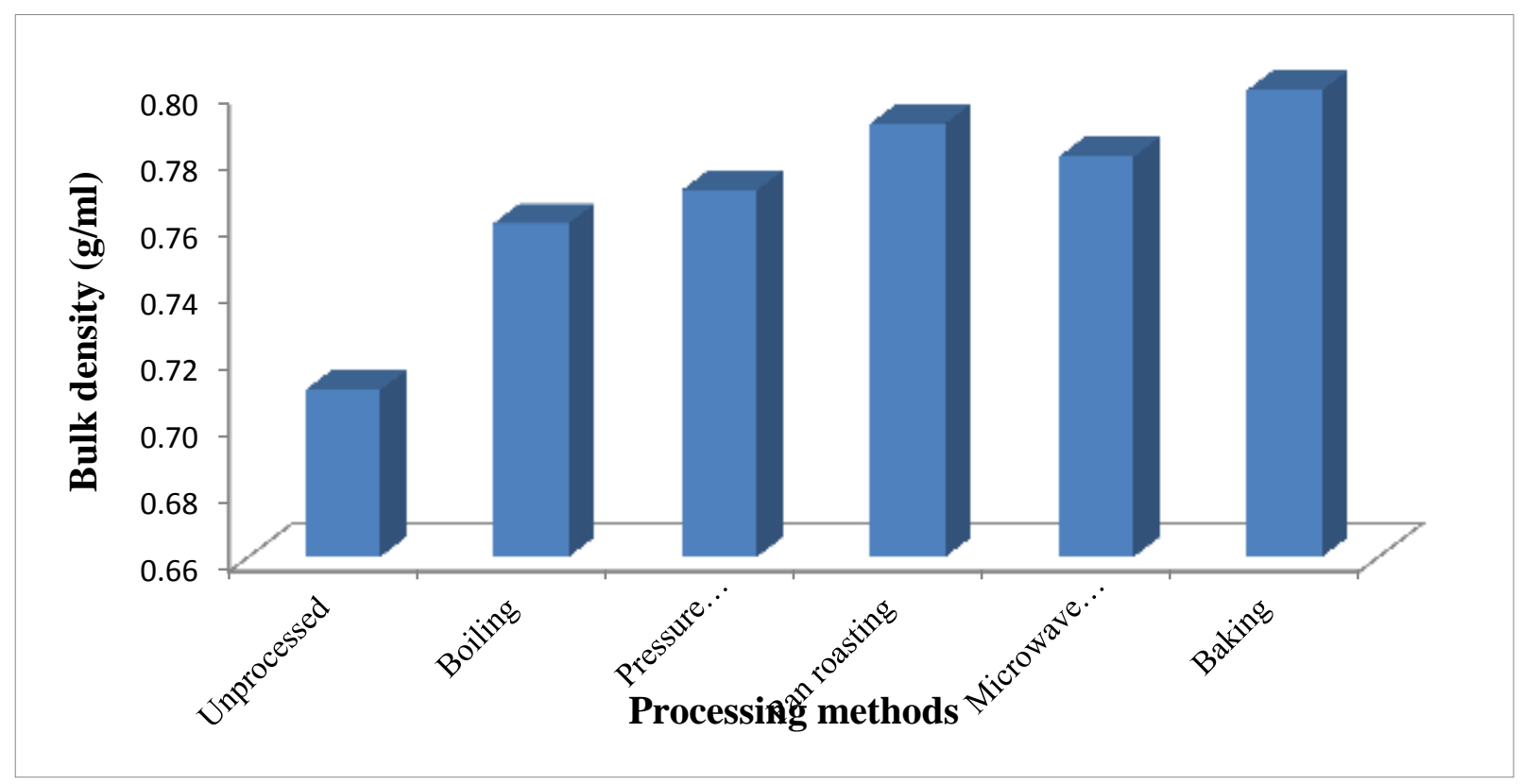

Fig 2 Bulk Density $(\mathrm{g} / \mathrm{ml})$ of processed jackfruit seeds 
Table 4 Effect of processing on functional properties of jackfruit seed flour

\begin{tabular}{|c|c|c|c|c|}
\hline \multirow{2}{*}{ Treatment } & \multicolumn{4}{|c|}{ Functional properties (\%) } \\
\cline { 2 - 5 } & $\begin{array}{c}\text { Water absorption } \\
\text { capacity }\end{array}$ & $\begin{array}{c}\text { Oil absorption } \\
\text { capacity }\end{array}$ & Swelling capacity & Solubility \\
\hline Unprocessed & $182.36 \pm 0.03^{\mathrm{f}}$ & $89.93 \pm 0.20^{\mathrm{e}}$ & $5.04 \pm 0.06^{\mathrm{b}}$ & $20.09 \pm 0.21^{\mathrm{b}}$ \\
\hline Boiling & $260.30 \pm 0.04^{\mathrm{b}}$ & $101.05 \pm 0.08^{\mathrm{d}}$ & $6.46 \pm 0.11^{\mathrm{a}}$ & $21.07 \pm 0.05^{\mathrm{a}}$ \\
\hline Pressure cooking & $282.71 \pm 0.02^{\mathrm{a}}$ & $101.26 \pm 0.72^{\mathrm{d}}$ & $6.24 \pm 0.10^{\mathrm{a}}$ & $20.51 \pm 0.28^{\mathrm{b}}$ \\
\hline Pan roasting & $201.37 \pm 0.03^{\mathrm{d}}$ & $115.80 \pm 0.92^{\mathrm{c}}$ & $4.90 \pm 0.02^{\mathrm{b}}$ & $15.63 \pm 0.20^{\mathrm{e}}$ \\
\hline Microwave roasting & $200.94 \pm 0.02^{\mathrm{e}}$ & $130.88 \pm 0.47^{\mathrm{b}}$ & $4.65 \pm 0.45^{\mathrm{b}}$ & $17.49 \pm 0.41^{\mathrm{c}}$ \\
\hline Baking & $201.95 \pm 0.03^{\mathrm{c}}$ & $164.76 \pm 1.17^{\mathrm{a}}$ & $4.92 \pm 0.06^{\mathrm{b}}$ & $16.31 \pm 0.22^{\mathrm{d}}$ \\
\hline F value & 58736 & 4461 & 18.95 & 258.82 \\
\hline S. Em. \pm & 0.12 & 0.82 & 0.23 & 0.29 \\
\hline C. D. at 1\% & $0.25^{* *}$ & $1.76^{* *}$ & $0.49^{* *}$ & $0.63^{* *}$ \\
\hline
\end{tabular}

**Significant at $1 \%$ level 
SJIF Impact Factor: 7.001| ISI I.F.Value:1.241| Journal DOI: 10.36713/epra2016 ISSN: 2455-7838(Online)

EPRA International Journal of Research and Development (IJRD)

Volume: 5 | Issue: 10 | October 2020 - Peer Reviewed Journal

Table 5 Particle size distribution of processed jackfruit seed flour

\begin{tabular}{|c|c|c|c|c|c|c|c|}
\hline \multirow{2}{*}{ Treatment } & \multicolumn{7}{|c|}{ BSS standards [Sieve opening $(\mu \mathrm{m})]$} \\
\hline & $60(250)$ & $85(180)$ & $100(150)$ & $150(105)$ & $200(75)$ & $240(63)$ & $300(53)$ \\
\hline Unprocessed & $15.76 \pm 0.74^{b}$ & $46.08 \pm 1.50^{\mathrm{a}}$ & $14.12 \pm 1.80^{\mathrm{a}}$ & $6.54 \pm 0.33^{c}$ & $14.02 \pm 0.48^{\mathrm{e}}$ & $3.96 \pm 0.04^{b}$ & $0.07 \pm 0.01^{\mathrm{d}}$ \\
\hline Boiling & $12.39 \pm 0.08^{\mathrm{d}}$ & $33.23 \pm 0.51^{\mathrm{cd}}$ & $5.24 \pm 0.65^{\mathrm{e}}$ & $11.27 \pm 0.88^{\mathrm{ab}}$ & $28.23 \pm 0.67^{b}$ & $10.61 \pm 0.16^{\mathrm{a}}$ & $0.13 \pm 0.06^{\mathrm{cd}}$ \\
\hline Pressure cooking & $12.25 \pm 0.55^{\mathrm{d}}$ & $31.96 \pm 1.92^{\mathrm{d}}$ & $8.95 \pm 0.47^{c d}$ & $10.21 \pm 0.81^{b}$ & $33.98 \pm 0.89 a$ & $2.36 \pm 0.71^{c}$ & $0.47 \pm 0.10^{b}$ \\
\hline Pan roasting & $14.51 \pm 0.93^{c}$ & $39.48 \pm 1.00^{\mathrm{b}}$ & $11.25 \pm 1.12^{\mathrm{b}}$ & $12.28 \pm 1.54 \mathrm{a}$ & $20.81 \pm 1.12^{c}$ & $2.38 \pm 0.14^{c}$ & $0.23 \pm 0.09 c$ \\
\hline Microwave roasting & $16.99 \pm 0.74^{a}$ & $35.22 \pm 1.60^{c}$ & $7.33 \pm 0.90^{\mathrm{d}}$ & $12.60 \pm 0.61^{\mathrm{a}}$ & $16.50 \pm 0.53^{d}$ & $10.10 \pm 0.48^{a}$ & $1.02 \pm 0.03^{\mathrm{a}}$ \\
\hline Baking & $14.73 \pm 0.31^{b c}$ & $34.47 \pm 0.37^{c}$ & $9.24 \pm 0.50^{c}$ & $12.55 \pm 0.87^{a}$ & $16.59 \pm 0.76^{\mathrm{d}}$ & $10.59 \pm 0.72^{a}$ & $0.80 \pm 0.13^{a}$ \\
\hline Mean & $14.44 \pm 1.83$ & $36.74 \pm 5.04$ & $9.35 \pm 3.02$ & $10.90 \pm 2.32$ & $21.69 \pm 7.38$ & $6.67 \pm 3.94$ & $0.47 \pm 0.38$ \\
\hline F value & 26.33 & 49.54 & 27.40 & 19.21 & 304.86 & 234.25 & 67.11 \\
\hline S. Em. \pm & 0.73 & 1.49 & 1.18 & 1.06 & 0.90 & 0.55 & 0.10 \\
\hline C. D. at $5 \%$ & $1.12^{*}$ & $2.30^{*}$ & $1.82^{*}$ & $1.64^{*}$ & $1.38^{*}$ & $0.84^{*}$ & $0.15^{*}$ \\
\hline
\end{tabular}

Figures in parenthesis indicate sieve opening $(\mu \mathrm{m})$

*Significant at $5 \%$ level 
SJIF Impact Factor: 7.001| ISI I.F.Value:1.241| Journal DOI: 10.36713/epra2016

ISSN: 2455-7838(Online)

\section{EPRA International Journal of Research and Development (IJRD)}

Volume: 5 | Issue: 10 | October 2020

- Peer Reviewed Journal

\section{REFERENCES}

1. Abraham, A and Jayamuthunagai, J., (2014). An analytical study on jackfruit seed flour and its incorporation in pasta. Res. J. Pharm. Bio Chem. Sci., 5(2): 1597-1610.

2. Akubor, P. I. and Obiegbuna, J. E., (2014). Effect of processing methods on the quality of flour and bread from African breadfruit kernel flour. Food Sci. Qua. Mgt., 24: 32-42.

3. Butool, S and Butool, M., (2013). Nutritional quality on value addition to jackfruit seed flour. Intr. J. Sci. Res., 4(4): 2406-2411.

4. Chowdhury, A. R., Bhattacharya, A. K. and Chattopadhyay, P., (2012). Study on functional properties of raw and blended jackfruit seed flour for food application. Indian J. Nat. Pro. Res., 3(3): 347-353.

5. Ejiofor, J. E., Beleya, E. A. and Onyenorah, N. I., (2014). The effect of processing methods on the functional and compositional properties of jackfruit seed flour. Intr. J Nutr. Food Sci., 3(3): 166-173.

6. Islam, M. S., Begum, R., Khatun, M., Dey, K. C., (2015). A study on nutritional and functional properties analysis of jackfruit seed flour and value addition to biscuits. Intr. J. Eng. Res. Tech., 4(12): 139-147.

7. Kaushal, P., Kumar, V. and Sharma, H. K., (2012) Comparative study of physico-chemical, functional, anti-nutritional and pasting properties of taro (Colocasia esculenta), rice (Oryza sativa), pegion pea (Cajanus cajan) flour and their blends. Food Sci. Technol., 48: 59-68. 